LAW, ETHICS, AND MEDICINE

\title{
Mr Marty's muddle: a superficial and selective case for euthanasia in Europe
}

J Keown

J Med Ethics 2006;32:29-33. doi: 10.1136/jme.2004.011148

Correspondence to: J Keown, Rose F Kennedy Professor of Christian Ethics, Kennedy Institute of Ethics, Georgetown University, 37th and $O$ Streets NW, Washington DC 20057, USA; ijk2@ georgetown.edu

Received 4 November 2004 Accepted for publication 22 February 2005
In April 2004 the Parliamentary Assembly of the Council of Europe debated a report from its Social, Health and Family Affairs Committee (the Marty Report), which questioned the Council of Europe's opposition to legalising euthanasia. This article exposes the Report's flaws, not least its superficiality and selectivity. e $\mathrm{n}$ the ongoing international debate about the legalisation of euthanasia a significant point of reference has been the recommendation against legalisation passed in 1999 by the Parliamentary Assembly of the Council of Europe. (The Council of Europe, a larger body than the European Union, was established in 1949 in order inter alia to defend human rights.) In Recommendation 1418 the Assembly urged member states "to respect and protect the dignity of terminally ill or dying persons in all respects". To this end it recommended a trio of means:

- recognising and protecting a terminally ill or dying person's right to comprehensive palliative care ...;

- protecting the terminally ill or dying person's right to selfdetermination ...;

- upholding the prohibition against intentionally taking the life of terminally ill or dying persons.

In relation to this third means it added:

- recognising that the right to life, especially with regard to a terminally ill or dying person, is guaranteed by the member states, in accordance with Article 2 of the European Convention on Human Rights which states that "no one shall be deprived of his life intentionally".

More recently, moves have been afoot to reconsider the Council's position. In September 2003 a report on euthanasia emerged from the Council's Social, Health and Family Affairs Committee (by a narrow majority). ${ }^{2}$ The Report comprised a draft resolution (of nine paragraphs) and an Explanatory Memorandum (of 63 paragraphs). The Memorandum was written by the Committee's rapporteur, Mr Dick Marty.

\section{THE REPORT'S REASONING AND RECOMMENDATIONS}

The Report stated that some doctors practised active, voluntary euthanasia on or assisted in suicide terminally ill patients who experienced "constant, unbearable pain and suffering without hope of any improvement". It added that this practice was usually "confined to the shadows of discretion or secrecy", that decisions may be taken in an arbitrary manner and depended on the presence of a "sympathetic" doctor or nurse. Moreover, pressures from the family could be more pernicious "if exercised in the dark and beyond any procedures or control" and it was "this reality that carries the greatest risk of abuse". Furthermore, penal and professional sanctions were very rare. Hence, there was a "striking divergence" between the law and practice, and this gap "must be reconciled if respect for the rule of law is to be maintained".

The closure of this gap was one reason, it claimed, why legislation had been passed in 2002 in the Netherlands and in Belgium to permit voluntary euthanasia subject to "rigorously regulated and controlled conditions". Such legislation was designed

\section{to bring such practices out of the grey area of uncertainty and potential abuse by establishing strict and transparent procedures, mechanisms and criteria which doctors and nursing staff have to observe in their decision-making.}

In addition, it was difficult to distinguish ethically between active voluntary euthanasia and the withholding or withdrawal of life-sustaining treatment when it was known that the patient would die sooner, which the Report described as "passive euthanasia".

The Report asserted:

Nobody has the right to impose on the terminally-ill and the dying the obligation to live out their life in unbearable suffering and anguish where they themselves have persistently expressed the wish to end it.

Moreover, it added, we now respected a person's choice to take their own life and avoided making value judgements about them, a development that could in no way be interpreted as a devaluation of human life.

Furthermore, palliative care could not take away unbearable pain and suffering in all cases and, in any event, the issue went beyond the alleviation of pain:

the degree of patients' own suffering, including mental anguish and loss of dignity that they feel, is something that 
only they can assess. Individuals suffering in the same situation may take different end-of-life decisions, but each human being's choice is deserving of respect.

In light of the above considerations the draft resolution recommended that member states:

- collect and analyse empirical evidence about end-of-life decisions ...;

- promote public discussion of such evidence ...;

- promote comparative analysis taking into account in particular the results of the legislation in the Netherlands and Belgium, "notably their effects on practice in the matter of euthanasia" and, in the light of the evidence and public discussion:

- consider whether legislation should be envisaged, where it has not already been introduced, to exempt from prosecution doctors who agree to help terminally-ill patients undergoing constant, unbearable pain and suffering without hope of any improvement in their condition, to end their lives at their persistent, voluntary and wellconsidered request, subject to prescribed rigorous and transparent conditions and procedures.

\section{SOME CRITICISMS}

The Report is gravely flawed, not least because it overstates the arguments for legalisation and downplays or ignores arguments against it.

\section{Arguments advanced by the Report The rule of law}

The Report claims that the rule of law supports legalisation. However, just as the opening paragraph of Recommendation 1418 notes that it is the vocation of the Council of Europe "to protect the dignity of all human beings and the rights which stem therefrom", so too the rule of law affords protection to all citizens, recognising their fundamental equality in dignity. Just as no-one is above the law, so no-one is beneath the law. A law permitting voluntary euthanasia would, for the first time, allow certain private citizens to kill other private citizens on the basis of the arbitrary judgement, historically denied in western law and medical ethics, that they would be better off dead. In short, the rule of law, to which the arbitrary exercise of power is repugnant, not least the power of life and death, tells against not for legalisation.

\section{"Closing the gap"}

The argument that there is a "striking divergence" between the law and medical practice and that the gap must be closed if respect for the rule of law is to be maintained is unconvincing. First, the assertion that there is a "striking" discrepancy between law and practice is controversial. Obtaining reliable data on the incidence of the offences of murder and assisted suicide by medical practitioners is, not surprisingly, difficult. The surveys cited by the Report allegedly demonstrating a "striking" discrepancy in countries where euthanasia and assisted suicide remain illegal must be read with caution. For example, the Report pointed out that, according to a survey of UK doctors, ${ }^{3}$ almost $60 \%$ replied that they had been asked to hasten death, of whom $32 \%$ had complied. These are not insubstantial figures. However, the figures require some qualification. The $60 \%$ includes $14 \%$ who were asked to let the patient die "through deliberate inaction", which the survey defined as "passive euthanasia", and the $32 \%$ who said they had taken active steps to end a patient's life represented only $9 \%$ of all the doctors who had been sent a questionnaire. Nor did the survey ask how often euthanasia had been performed. Moreover, unlike the three comprehensive surveys into end of life decision making in the Netherlands carried out since 1991 by Professor van der Maas et $a{ }^{4-6}$ the UK survey, as its definition of "passive euthanasia" indicates, did not consistently define "euthanasia" in terms of the intentional hastening of death, which may have led to some confusion; nor did the UK survey involve interviews with doctors, which van der Maas found important in clarifying the thinking of his respondents in distinguishing euthanasia from other end of life decisions. ${ }^{7}$

Another UK survey, commissioned by the BBC and involving a sample of health professionals over twice the size of the survey cited by the Report, disclosed that only $4 \%$ had assisted in suicide, either by providing drugs or advice. ${ }^{8}$ Similarly, a US survey found that only $6 \%$ of physicians there had performed euthanasia or assisted suicide, the author of the survey concluding that it was a "rare" event." Professor van der Maas has written that the proportion of deaths in the USA from euthanasia and physician assisted suicide is likely to be "small". ${ }^{10}$

Secondly, even if there were a serious discrepancy between the law and the practice of euthanasia, it would not follow that the gap would be narrowed by relaxing the law. Many criminal laws are regularly broken. Some prohibitions, such as the law against possessing hard drugs, are frequently breached without detection, but it does not follow that the law should therefore be relaxed to accommodate those who snort coke.

Thirdly, if the law against voluntary euthanasia is occasionally broken, so too is the law against non-voluntary euthanasia (both in jurisdictions where, like the UK and the USA, voluntary euthanasia is illegal and in jurisdictions, notably the Netherlands, where it is legal). If the Report believes the gap between the law and the practice of voluntary euthanasia militates in favour of legalisation, then why not the gap between the law and practice of nonvoluntary euthanasia?

Fourthly, the Report seems to assume that if voluntary euthanasia is practised it should therefore be condoned. Revealingly, the Draft Resolution does not propose that, in the light of whatever evidence may emerge from studies into the incidence of euthanasia, there should be a review of various options, including improving the provision of quality palliative care and/or tighter enforcement of the criminal law. It proposes solely that member states consider legalising euthanasia. That this is the Report's not-too-skilfully-hidden agenda is also clear from its underlying argument in principle for reform, for, if there is a right to voluntary euthanasia, why should it not be recognised by law whatever the evidence might disclose about levels of current practice? Moreover, what if, as much evidence suggests, ${ }^{11}{ }^{12}$ voluntary euthanasia is carried out on patients whose autonomy is compromised by clinical depression or whose suffering could have been alleviated by palliative care? In other words, why does the Report seem to assume that the problem with the alleged gap between the criminal law and medical practice lies with the former rather than the latter, that the law is bad and the practice good? Was Dr Kevorkian a model of good medical practice? Of the 69 people he assisted in suicide only a quarter were terminally ill. ${ }^{13}$ Why assume that the law should accommodate Kevorkians rather than incarcerate them?

Finally, relaxing the law to allow euthanasia to be performed in certain circumstances would not mean that euthanasia would be performed only in those circumstances. Legislative proposals for regulating euthanasia typically set out procedural requirements aimed at monitoring the practice of euthanasia; they do not seek to prohibit the practice of euthanasia that fails to satisfy those requirements. In other words, the potential for "abuse", for breaking the law against murder and assisted suicide, remains. Indeed, it 
may well be that legalising euthanasia in certain circumstances would result in euthanasia in other circumstances being regarded by the criminal justice system as less, not more, serious: a lower, not a higher priority. It is noteworthy that in the Netherlands very few doctors have been prosecuted for breaching the requirements for lawful euthanasia, and that those doctors who have been convicted of murder have typically been dealt with by the courts with remarkable leniency.

\section{The Dutch example}

The Report implicitly endorses the Dutch and Belgian legislation. It describes the procedures prescribed by the legislation as "strict and transparent" and claims that the Dutch surveys have shown that "close monitoring" is possible. There is a problem with all this: the Dutch surveys show precisely the opposite.

For example, the so-called "strict and transparent procedures" in the Dutch legislation (which essentially enshrine guidelines that have been in operation since 1984 when the Dutch Supreme Court first declared voluntary euthanasia lawful) include a requirement for doctors to report all cases to the authorities. The three Dutch surveys carried out by Professor van der Maas et al have demonstrated that a clear majority of cases have been covered up by doctors. ${ }^{14}{ }^{15}$ In other words, in the bulk of cases there has not even been an opportunity for control. Even in relation to the minority of cases that have been reported, the reports are filed by the doctors themselves, who are hardly likely to disclose that they have breached the guidelines. The surveys indicate, moreover, that failure to report is by no means the only important requirement that has been widely ignored, with virtual impunity, by Dutch doctors. Thousands of Dutch patients have been killed without request.

The conspicuous failure of the Dutch regulatory mechanisms over the last 20 years has been repeatedly demonstrated by commentators of whose work the Report seems oblivious. ${ }^{12} 1617$ (The focus of this paper is on the Dutch rather than the Belgian experience, partly because Dutch law has approved euthanasia for much longer-and there is accordingly more evidence about Dutch practice-and partly because the Belgian law largely emulates the Dutch law.) Also notably absent from the Report is any reference to the serious concerns that have been expressed, not least about the non-voluntary euthanasia of disabled newborns, by the UN Human Rights Committee. ${ }^{18}$

In short, there is indeed a "striking divergence", but it is between the law and the practice of euthanasia in the Netherlands. Another gap, hardly less striking, is that between the reality of Dutch practice and its (mis)representation by the Report.

\section{Changing attitudes toward suicide}

The Report also presents a contentious interpretation of changing attitudes to suicide. In England, for example, the decriminalisation of suicide by the Suicide Act 1961 reflected, as the Government of the time made abundantly clear, ${ }^{19}$ not a condonation of suicide but a realisation that criminal punishment was an inappropriate way of dealing with suicidal persons. As Lord Bingham confirmed in the Pretty case, ${ }^{20}$ in which the House of Lords rejected an alleged right to assisted suicide, the Suicide Act 1961 conferred no right on anyone to commit suicide.

\section{Public opinion}

The Report claims that public opinion polls show a majority in favour of legalisation. Such polls must be read cautiously, but even assuming the claim to be true it could hardly be allowed to dictate law and public policy any more than a finding that a majority of people favour capital punishment.

\section{Equating euthanasia with non-treatment}

The Report's equation of "euthanasia" with the withdrawal of life-sustaining treatment when the shortening of life is foreseen, which it describes as "passive euthanasia", is misleading. It defines "euthanasia" as "any medical act intended to end a patient's life at his or her persistent, carefully considered and voluntary request in order to relieve unbearable suffering". How, then, can the withdrawal of treatment when the doctor merely foresees that it will shorten life count, on the Report's definition, as "euthanasia"? For one thing, there is no "act" and even if there is foresight of death it does not follow that there is also an intention to end life. Simply to conflate these two forms of conduct, which there are good ethical reasons to regard as distinct, is undeniably controversial and invites confusion. Moreover, by defining "euthanasia" as "active, voluntary euthanasia", the Report adopts the controversially narrow Dutch definition. One danger of this definition is that it can be used (as it has been by the Dutch) to deflect discussion of non-voluntary and involuntary euthanasia on the grounds that they are not "euthanasia" and therefore lie outside the boundaries of the euthanasia debate.

\section{Misrepresenting the case against euthanasia}

The Report states that opponents of legalisation reject the claim that

each individual, out of respect for his or her dignity and value, has a right to take decisions concerning his or her own life and death in accordance with his or her own values and beliefs, as long as no harm is done to others, and not to have these imposed.

It would have been less misleading to state that opponents of euthanasia, while supporting the right of patients to make a range of decisions concerning their medical treatment, reject one decision as being incompatible with the patient's dignity and value: the decision to be intentionally killed, or to be helped to commit suicide. Moreover, to prohibit that choice does not deny the patient's dignity but affirms it, just as disallowing other choices that a person may want to make, such as to be executed rather than imprisoned, equally respects his or her inalienable dignity. The fact that, through depression or pain or loneliness, some patients may lose sight of their worth is no argument for endorsing their misguided judgement that their life is no longer worth living. Were the law to allow patients to be intentionally killed by their doctors, it would be accepting that there are two categories of patients: those whose lives are worth living, and those who are better off dead. What signal, moreover, would that send out to people who are sick, elderly, disabled, or dying?

The Marty Report goes on to imply that opponents of euthanasia are imposing on terminally ill people "the obligation to live out their life in unbearable suffering and anguish ...". On the contrary, many of the leading opponents of euthanasia, such as Dame Cicely Saunders, foundress of the hospice movement, have devoted their lives to the alleviation of suffering and anguish. Again, opponents of euthanasia recognise the right of patients to refuse treatments because they are futile or too burdensome, even if it is foreseen that death will come sooner. Those opposed to euthanasia do not believe that life should be preserved at all costs; that is a cheap caricature. 


\section{Counterarguments not met}

The Report glosses over several important counterarguments. To take but one, it mentions but nowhere rebuts the counterargument that legalising voluntary euthanasia leads as a matter of practice and of logic to non-voluntary euthanasia. The counterargument runs that the slide will occur as a matter of practice because "safeguards" to prevent it cannot be made effective, and as a matter of logic because the case for voluntary euthanasia for terminally ill people contains the seeds of its own extension to those who are not terminally ill or to those who cannot request it.

The failure of "safeguards" as a matter of practice is amply demonstrated by the Dutch experience, but that experience also illustrates the force of the logical "slippery slope", a product of the unresolved tension in the argument for voluntary euthanasia between patient autonomy and patient welfare.

Respect for patient autonomy

The Report states that opponents of euthanasia dismiss

the individual's right to take decisions concerning his or her own life and death in accordance with his or her own beliefs and values, as long as no harm is done to others.

It concludes that consideration should be given to exempt from prosecution doctors who agree to help

terminally-ill patients undergoing constant, unbearable pain and suffering without hope of any improvement in their condition, to end their lives at their persistent, voluntary and well-considered request ...

However, if there is a right to make decisions concerning life and death in accordance with one's own values and beliefs why should euthanasia not be available to any autonomous person who believes, for whatever reason (terminal, chronic or mental illness, "tiredness of life", bereavement, divorce, unemployment, lost election ...) that their life is no longer "worth living"? By imposing conditions such as "terminal illness" on candidates for euthanasia, why is the Report not denying each individual's "right to take decisions concerning his or her own life and death in accordance with his or her own values and beliefs"?

Interestingly, the former Dutch Health Minister, Mrs Borst, a leading defender of the Dutch euthanasia regime, has stated that she thinks elderly people should be able to obtain suicide pills to take if they simply felt "tired of living". Mr Marty could not claim to be unaware of her viewpoint-it was pointed out by the author in his response to Mrs Borst's speech at a hearing on euthanasia held by his Committee in Paris in 2002 (a hearing which, like the Report, was unbalanced: invited speakers in favour of legalisation markedly outnumbered those against).

\section{Respect for patient welfare: the life "not worth living"'}

No responsible doctor would kill a patient merely because the patient requested it, however autonomously, any more than a responsible doctor would amputate a healthy leg just because the patient requested it. Indeed, in the Netherlands doctors refuse many autonomous requests for euthanasia. The doctor grants the request only if the doctor personally judges that the patient is right in thinking that death would be a benefit. If the doctor, however, thinks he or she can make this judgement-that the patient would be better off dead-in relation to a patient who asks for euthanasia, why cannot the doctor make that decision in relation to a patient in the same situation who is unable to request it? In other words, if death would benefit the patient why should it be denied the patient merely because of incompetence?

In 1996, two Dutch Courts of Appeal, adapting the reasoning previously used by the courts to justify voluntary euthanasia, held it lawful for doctors to give lethal injections to disabled babies, ${ }^{21}$ which illustrates the force of this counterargument. It was, moreover, recently reported that Dutch doctors are drafting protocols for euthanising children aged under 12 years (which is the minimum age specified in the present legislation) and that Members of Parliament from the ruling party in Belgium have introduced a Bill that would extend euthanasia to minors. ${ }^{22}$ As this trend confirms, once the rhetorical mask of autonomy is stripped away, the true face of euthanasia is revealed: the judgement that certain patients are better off dead. The Marty Report is an exercise in failed cosmetic surgery.

\section{CONCLUSION}

Mr Marty's Explanatory Memorandum concludes:

As a lawyer and a legislator, I note that all over the world, doctors are ending the lives of patients, often in secrecy and with a sense of guilt. The law seems to want to ignore this fact of life, whereas it ought to have the courage to address it. Decriminalising euthanasia, rather than keeping the ban, might enable us to better supervise it and also prevent it.

He seems unaware that around the world the case for legalising voluntary euthanasia has already been considered by "lawyers and legislators" and that they have, with few exceptions, rejected that case. It is puzzling why the Report fails even to mention important and relevant publications such as that of the New York State Task Force, ${ }^{11}$ whose members, both pro- and anti-euthanasia, unanimously rejected legalisation on the ground that it would be socially disastrous.

The core argument informing the Marty Report-that because euthanasia takes place illegally the Council of Europe should, in the light of empirical evidence, consider legalising it so as to "bring it out into the open" where it can be better "controlled"- has been refuted by the evidence from the Netherlands. This is hardly surprising: if some doctors are prepared, when euthanasia is illegal, to ignore the law of murder which prohibits it, why should we expect them, when euthanasia is legal, to observe the guidelines that permit it?

The Marty Report appeared in September 2003. It was strongly criticised by the Council of Europe's Committee on Legal Affairs and Human Rights later that month. ${ }^{23}$ This Committee concluded (at paragraph 25): "The Dutch situation demonstrates that legalizing euthanasia and assisted suicide, far from introducing greater controls, simply introduces more euthanasia and more assisted suicide". The Report was debated in April 2004 by the Parliamentary Assembly of the Council of Europe. ${ }^{24}$ The Assembly decided not to vote on the text but to refer it back to the Committee so it could prepare a new text bringing together the widely diverging viewpoints expressed in the debate. It is to be hoped that any new text avoids the pitfalls of superficiality and selectivity into which its predecessor so clumsily fell.

Competing interests: none declared

\section{REFERENCES}

1 Parliamentary Assembly of the Council of Europe. Protection of the human rights and dignity of the terminally ill and the dying. (Recommendation 1418) 1999. http://assembly.coe.int/Documents/AdoptedText/ta99/ erec1418.htm \#1 (accessed 21 Mar 2005). 
2 Social, Health and Family Affairs Committee, Council of Europe, rapporteur D Marty. Euthanasia. (Doc. 9898) 10 September 2003. http:// assembly.coe.int/Documents/WorkingDocs/Doc03/EDOC9898.htm (accessed 21 Mar 2005).

3 Ward BJ, Tate PA. Attitudes among NHS doctors to requests for euthanasia. BMJ 1994;308:1332-4.

4 van der Maas PJ, van Delden JMM, Pijnenborg L. Medische beslissingen rond het levenseinde. Het onderzoek voor de Commissie onderzoek medische praktijk inzake euthanasia. [Euthanasia and other medical decisions concerning the end of life.] The Hague: SDU Uitgeverii Plantijnstraat, 1991.

5 van der Wal G, van der Maas PJ. Euthanasie en andere medische beslissingen rond het levenseinde. De praktiik en de meldingsprocedure. [Euthanasia, physician-assisted suicide and other medical practices involving the end of life.] The Hague: SDU Uitgevers, 1996.

6 van der Wal G, van der Heide A, Onwuteaka-Philipsen BD, et al. Medische besluitvorming aan het einde van het leven: De praktijk en de toetsingprocedure euthanasiae. [Medical decision making at the end of life: the practice and the verification procedure (in cases of) euthanasia.] Utrecht: De Tijdstroom, 2003.

7 van der Maas PJ, van Delden JMM, Pijnenborg L. Medische beslissingen rond het levenseinde. Het onderzoek voor de Commissie onderzoek medische praktijk inzake euthanasia. [Euthanasia and other medical decisions concerning the end of life.] The Hague: SDU Uitgeverij Plantijnstraat 1991:162. Cited in: Keown J. Euthanasia, ethics and public policy. Cambridge: Cambridge University Press, 2002:94.

8 McLean SAM, Britton A. Sometimes a small victory. Glasgow: Institute of Law and Ethics in Medicine, University of Glasgow, 1996:31-2 (appendix III, table 17).

9 Meier DE, Emmons CA, Wallenstein S, et al. A national survey of physicianassisted suicide and euthanasia in the United States. N Engl J Med 1998;338:1193-201.

10 van der Maas P, Emanuel LL. Factual findings. In: Emanuel LL, ed. Regulating how we die. Cambridge, MA: Harvard University Press, 1998:151.

11 New York State Task Force on Life and the Law. When death is sought: assisted suicide and euthanasia in the medical context. New York, NY: New York State Task Force on Life and the Law, 1994
12 Keown J. Euthanasia: ethics and public policy. Cambridge: Cambridge University Press, 2002

13 Roscoe L, Malphurs J, Dragovic L, et al. Dr Jack Kevorkian and cases of euthanasia in Oakland County, Michigan, 1990-1998 [Letter]. N Engl J Med 2000;343:1735-6.

14 Keown J. Euthanasia, ethics and public policy. Cambridge: Cambridge University Press, 2002:113,132.

15 Fenigsen R. Dutch euthanasia: the new government ordered survey. Issues Law Med 2004;20:73,77.

16 Gomez CF. Regulating death: euthanasia and the case of the Netherlands. New York, NY: Free Press, 1991.

17 Hendin H. Seduced by death: doctors, patients and assisted suicide, revised edition. New York, NY: Norton, 1998.

18 United Nations, International Covenant on Civil and Political Rights. Concluding observations of the Human Rights Committee: Netherlands. Paras 5-6. (CCPR/CO/72/NET.) 27 August 2001. http://www.unhchr.ch/tbs/ doc.nsf/(Symbol)/CCPR.CO.72.NET.En?Opendocument (accessed 21 Mar 2005).

19 Keown J. Euthanasia, ethics and public policy. Cambridge: Cambridge University Press, 2002:64-66.

20 Regina (Pretty) v. Director of Public Prosecutions (Secretary of State for the Home Department Intervening) [2001] 3 WLR, 1598.

21 Jochemsen $\mathbf{H}$. Dutch court decisions on nonvoluntary euthanasia critically reviewed. Issues Law Med 1998;13:447-58.

22 Reuters. Dutch doctors drafting protocols for child euthanasia. Bioedge, 10 September, no. 134. http://www.australasianbioethics.org/Newsletters/ 134-2004-09-10.html (accessed 21 Mar 2005).

23 Opinion of the Legal Affairs and Human Rights Committee of the Council of Europe. Rapporteur K McNamara, United Kingdom, Socialist Group. Euthanasia. (doc. 9923) 23 September 2004. http:// assembly.coe.int/Documents/WorkingDocs/Doc03/EDOC9923.htm (accessed 21 Mar 2005)

24 Council of Europe. News item. 2000-. http://www.coe.int/NewsSearch/ InternetNewsSearch.asp?KW = euthanasia\&lmLangue = 1\&Submit $=$ Search\&L = (accessed 21 Mar 2005) 